\title{
O sentido de perspectiva no El Espectador de Ortega y Gasset"
}

\author{
José Mauricio de Carvalho \\ Vanessa da Costa Bessa ${ }^{2}$ \\ Universidade Federal de São João del-Rei
}

O presente artigo mostra como o filósofo espanhol José Ortega y Gasset estabelece a perspectiva do sujeito como forma de acesso à verdade. São examinados os vários aspectos da questão elaborada inicialmente como problema ontognoseológico, através do qual o filósofo espera superar a redução da realidade à matéria ou espírito. Indica-se, ainda, que o problema também possui, no raciovitalismo orteguiano, implicações morais pela fidelidade que proclama a um fundo pessoal insubornável. A fidelidade a este fundo íntimo não significa obediência aos desejos, já que a ação humana demanda análise racional e respeito aos valores nucleares da sociedade.

Palavras-chave: Perspectiva - Sentido - Filosofia - Raciovitalismo Ortega y Gasset
In this article we study how the Spanish philosopher José Ortega y Gasset establishes the perspective of the subject as a mean of access to the truth. We examine various aspects of the issue initially elaborated as an ontological problem, whereby the philosopher hopes to overcome the reduction of reality to the matter or spirit. It is also indicated that the problem has, in Orteguian rationvitalism, moral implications by the fidelity that proclaims an incorruptible personal background. The fidelity to this close fund doesn't mean obedience to the wishes/desires, because it demands rational analysis and respect for the core values of the society.

Keywords: Perspective - Sense Philosophy - Rationvitalism - Ortega y Gasset

\section{Considerações iniciais}

\footnotetext{
noção de perspectiva representa na filosofia orteguiana o reconhecimento Ade que é o olhar do indivíduo o único modo de se chegar à realidade. Esta forma de acesso ao fundo do real foi estabelecida no ensaio Verdad y Perspectiva (1916) (El Espectador I). Conhecer a realidade é um problema essencial da filosofia.

* Sense of perspective in El Espectador by Ortega y Gasset

${ }^{1}$ Professor do Departamento de Filosofia da UFSJ. Endereço para correspondências: Departamento de Filosofia da UFSJ, Praça Dom Helvécio, 74, Fábricas, São João del-Rei, MG, 36310-160 (mauricio@ufsj.edu.br).

${ }^{2}$ Bolsista do PIBIC/FAPEMIG.
} 
Com a noção de perspectiva Ortega y Gasset ${ }^{3}$ procura entender o real sem reduzi-lo ao que dizia o materialismo marxista ou positivista ou ainda o idealismo hegeliano, conforme ele explica nas Meditaciones del Quijote. Este era o desafio do início do século XX e possuía relação não com as realizações da ciência, mas com o que ela se propunha no desvendamento da vida humana e com os pressupostos que difundia, a saber: a verdade científica é uma cópia da realidade da natureza, a ciência fornece o único método válido para o estudo da realidade, inclusive os problemas morais, políticos ou sociais.

Em Verdad y Perspectiva Ortega y Gasset afirma que cada homem tem uma missão sobre a verdade, e que esta verdade é não só cognitiva, mas pessoal. $\mathrm{O}$ assunto será desenvolvido em diversos ensaios de El Espectado ${ }^{4}$ : Ideas sobre Pio Baroja, El origen deportivo del Estado, De Madrid a Astúrias o los dos paisajes, Elogio del Murciélago, Temas de viaje, La interpretación bélica de la história, Hegel y América, Divagación ante el retrato de la marquesa de Santillana.

Nos textos mencionados acima, Ortega y Gasset trata de questões nucleares de seu pensamento ${ }^{5}$. O modo como a perspectiva é tratada em El Espectador é o problema deste artigo. El Espectador é um conjunto de sete volumes com ensaios e artigos elaborados durante um período bastante longo entre os anos de 1916 e 1934 e que estão no volume II das Obras Completas do autor.

\footnotetext{
${ }^{3}$ José Ortega y Gasset, escritor e filósofo espanhol, nasceu e morreu em Madrid, respectivamente nos anos de 1883 e 1955. Começou seus estudos no Colégio Jesuíta próximo à Málaga (Andaluzia). Mais tarde estudou nas Universidades de Marburgo, Leipzig e Berlin (Alemanha). Voltando à pátria em 1914 tornou-se professor na Universidade de Madrid. Em 1923 fundou a conhecida Revista do Ocidente. Em 1931 teve breve experiência política, elegendo-se deputado da República. Com a explosão da Guerra Civil em 1936 é obrigado a deixar a cátedra e refugiar-se no exterior. Reside muito tempo longe de seu país em vários países: França, Holanda, Portugal e Alemanha, voltando à Espanha em 1948. No mesmo ano funda com Julián Marías o Instituto de Humanidades. Suas obras mais importantes são: Meditações do Quixote, A Desumanização da Arte, A rebelião das Massas e $O$ Homem e a Gente. Ortega y Gasset desenvolveu uma filosofia da vida, partindo de fonte diversa da empregada por Unamuno. Ele foi discípulo de Herman Cohen. "Notam-se nele, além da escola neokantiana, as influências do historicismo de Dilthey, do relativismo de Simmel, do intuicionismo de Bergson e do vitalismo em geral" (SCIACCA, 1968, v. III, p. 199).

${ }^{4}$ El Espectador é o nome dado a sete livros escritos entre 1916 e 1934, que estão reunidos no volume $2^{\circ}$ das Obras Completas de José Ortega y Gasset publicada pela Alianza Editorial de Madrid. Os ensaios reunidos em El Espectador constituem um marco da passagem da fase inicial para a etapa decisiva do pensamento orteguiano. Momento decisivo é aquele em que o filósofo apresenta de forma amadurecida e própria os aspectos nucleares de sua meditação filosófica. Essa fase decisiva inicia-se com a publicação de Meditações do Quixote onde o filósofo define a vida em circunstância como a realidade radical a ser examinada como problema nuclear do filosofar. É essa problemática que está presente em El Espectador.

${ }^{5}$ Ortega y Gasset tratou dos problemas nucleares da filosofia contemporânea. O desafio da filosofia nos anos em que foram escritos os ensaios de El Espectador era mostrar os limites da ciência moderna. Construída sob as referências do positivismo, que tinha por modelo a Física, ela era destituída de preocupação humanista. Esse modelo de ciência dava pouca atenção ao valor e à responsabilidade pessoal de construir um sentido para a vida. Aqueles dias viveram uma crise ampla também porque a $1^{\text {a }}$. Guerra Mundial destruiu a visão bem acabada de modernidade representada pela belle époque e lançou a humanidade ocidental na incerteza.
} 
No livro muitos assuntos são tratados, entre os quais o problema da perspectiva que é fundamental no raciovitalismo orteguiano, sendo que a perspectiva está ligada à circunstância.

A questão da perspectiva impacta inicialmente os problemas epistemológicos, pois influi no conhecimento que brota do horizonte vital de cada um. Neste caso o filósofo se empenhará em indicar que a verdade elaborada em perspectiva não fica invalidada pelos saberes objetivos da cultura como o elaborado pela ciência.

O problema também influi na ontologia orteguiana. É que se admitirmos que viver é a realidade fundamental que os filósofos buscaram em toda a história da filosofia com o propósito de esclarecer o que somos nós e o que é o mundo, estamos diante de algo que se manifesta em perspectiva, diz Ortega y Gasset, irredutível a um objeto qualquer.

Embora a questão da perspectiva surja como problema ontognoseológico também possui implicações morais. Se cada pessoa tem uma perspectiva e a verdade se apresenta a ela de modo singular, o seu compromisso com os outros homens inclui ser fiel à sua perspectiva, respeitá-la, pois assim contribuirá com o restante da humanidade para quem sua perspectiva é inatingível. A fidelidade à própria perspectiva reveste-se de comprometimento moral, pois os aspectos constitutivos das escolhas surgem no inevitável enfrentamento da circunstância.

O problema da perspectiva realça o valor do diálogo, pois somente ele nos leva à visão de outras pessoas. A perspectiva dos demais homens observa Ortega y Gasset, de algum modo contribui para enriquecer o meu mundo singular e ajuda descobrir o que há de oculto na realidade que não aparece para mim. Em contrapartida, o diálogo apenas se completa caso comuniquemos nossa ótica do mundo.

A autêntica comunicação leva cada pessoa a compartilhar sua perspectiva abrindo um canal de intercâmbio na insuperável solidão ontológica que marca a vida de todos nós. Assim o é porque cada indivíduo anseia exprimir sua perspectiva e descobrir a dos demais. Além disto, a comunicação coloca os homens em contato com as descobertas de outras construções compartilhadas como o são: a ciência, a filosofia, a religião, etc.

O mergulho na insegurança dos povos do ocidente resultou da destruição das estruturas sociais, políticas e intelectuais que conferiam uma certa estabilidade à vida pessoal. No Brasil, o contato com a obra orteguiana foi feito através de Gilberto de Mello Kujawski (nascido em 1925), Ubiratan Borges de Macedo (1937-2008) e Nelson Saldanha (nascido em 1931). Além da divulgação do pensamento orteguiano, todos os autores avançaram interpretações e ideias próprias, valendo-se dos conceitos fundamentais do raciovitalismo orteguiano. No meio acadêmico o filósofo começa a ser mais conhecido recentemente com muitas dissertações de mestrado e teses de doutoramento dedicadas às suas ideias. Hoje Ortega y Gasset é considerado o mais destacado filósofo espanhol do século XX e um dos mais importantes da Europa no período. A Revista de Estudios Orteguianos publicada pela Fundación Ortega y Gasset de Madri, desde o ano 2000, além dos estudos sobre o filósofo traz resenhas e notícias de dissertações e teses sobre Ortega y Gasset em todo o mundo. Através dela é possível acompanhar o avanço dos estudos sobre o filósofo, as centenas de obras publicadas e teses defendidas sobre suas ideias. 


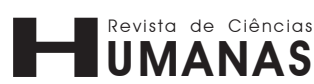

No artigo desenvolveremos os seguintes itens: a relação epistemológica entre perspectiva e verdade, a existência da multiplicidade de perspectivas como expressão do modo de ver humano, o emprego da perspectiva na superação do intelectualismo, a importância da fidelidade à própria perspectiva e o modo de inserir a perspectiva de cada pessoa na cultura.

\section{Perspectiva e realidade}

O problema da perspectiva aparece no início do volume I de El Espectador como questão gnoseológica. $\mathrm{O}$ mundo emerge para o homem como realidade multifacetada que o coloca frente ao significado da verdade e do seu conhecimento. O saber a verdade tradicionalmente foi tratado como a busca de uma realidade universal, supunha-se haver uma única verdade e uma única forma de acesso a ela. Assim acreditaram os primeiros metafísicos na antiga Grécia.

No primeiro ensaio de El Espectador I intitulado Verdad y Perspectiva, o filósofo refere-se à busca da verdade como algo a que o homem se empenha com ânsia semelhante à do náufrago. O sobrevivente do naufrágio espera encontrar socorro no horizonte para onde dirige seu olhar. $\mathrm{O}$ olhar de náufrago para o mundo coloca o homem diante "da reflexão sobre o ser das coisas" (p. 16) porque o horizonte vital está cheio de coisas que aparecem para ele. Cabe lembrar que o horizonte vital é parte da circunstância, como esclarece Cascalès (1957) do seguinte modo: "eu não escolho minha circunstância, mas é ela que define o horizonte vital de minha vida" (p. 34). O horizonte não é apenas constituído por um conjunto de seres que se manifestam para o indivíduo, estes seres estão à volta do sujeito que é o centro do que o contorna explica o filósofo em Adán en el Paraíso (1910).

Ortega y Gasset lembra a República de Platão (438-348 a.C.), livro onde o grego refere-se à singularidade com que os filósofos contemplam o mundo. Embora o cosmo esteja cheio de coisas e todos assim o percebam, os filósofos olham para estas coisas procurando entender o que elas são verdadeiramente. Estes filósofos adotam uma contemplação muito singular da realidade que o pensador grego resume na expressão amigos do mirar.

A lembrança da filosofia platônica serve a Ortega y Gasset quando ele olha a manifestação espontânea dos seres à pupila humana. Alguns homens querem mais do que mirar esta manifestação espontânea dos seres reconhece Ortega y Gasset, eles teorizam sobre a realidade. No ensaio Verdad y Perspectiva, o filósofo recorda que a explicação teórica sobre o sentido dos seres levou à suposição pelos antigos gregos de uma realidade oculta. Aos filósofos cabia desvendá-la, tirar o véu que a ocultava, o que os antigos helenos traduziam pelo termo alethéia. 
O horizonte do sujeito ordinariamente não chega a esta realidade oculta, só um olhar tão atento como o do náufrago para o horizonte é capaz de perceber o que ordinariamente não se vê.

Este olhar para o que transcende o que se manifesta, aparece primeiramente no início das Meditaciones del Quijote (1914). Naquele livro Ortega y Gasset utiliza uma metáfora em que o bosque representa a realidade. O filósofo diz que as árvores que contemplamos enquanto caminhamos não deixam ver o bosque em sua integridade. Com esta figura de linguagem admite algo invisível à perspectiva do contemplador. Em outras palavras, ao nos deslocarmos entre as árvores que formam o bosque, vemos suas paisagens visíveis, mas admitimos que além delas se encontre uma outra paisagem invisível e imperceptível à contemplação. Eis o que escreveu na meditação preliminar do seu livro:

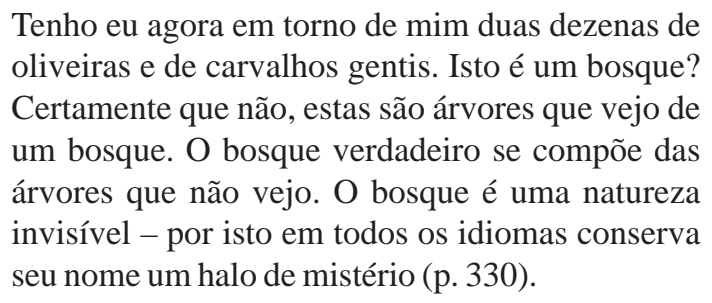

Árvores de carvalhos e oliveiras reunidas constituem um bosque? Ortega y Gasset observa que elas são vistas na perspectiva de quem as vê. Elas não nos surgem de um estudo científico sobre a mata temperada. É só como experiência vital que o bosque comporta uma paisagem invisível, porque apenas neste caso ficam sempre fora do relato as árvores que não aparecem no horizonte vivido, mas que estão lá integrando o bosque.

Ao retornar ao assunto tratado nas Meditaciones no ensaio Verdad y Perspectiva o filósofo nos coloca diante de uma nova questão. Será que a perspectiva do sujeito é falsa porque seu horizonte vital não revela a paisagem invisível? Ele recorda que assim foi pensado em diferentes momentos da história da filosofia produzindo a falsa crença de que: "o ponto de vista do indivíduo é falso" (idem, p. 18). Desta crença vieram conclusões igualmente erradas, primeiramente do ceticismo, para o qual a verdade não existe e depois do racionalismo, teoria segundo a qual a verdade existe unicamente como realidade supra-individual. Ortega y Gasset rejeita ambas as conclusões ao afirmar: “o ponto de vista individual me parece o único do qual se pode olhar o mundo em sua verdade" (idem, p. 18). A realidade só pode ser contemplada, portanto, mediante a perspectiva de cada pessoa. Cada homem tem a missão personalíssima de falar da verdade que ele, e apenas ele, percebe. 


\title{
Hüüăas
}

Como o filósofo procura superar as ditas "falsas" crenças do ceticismo e do racionalismo? Ele entende que a realidade possui diversas formas de se apresentar ou diversos planos para aparecer como afirma no texto abaixo:

\begin{abstract}
A realidade, pois, se oferece em perspectivas individuais. O que para um está em último plano, se acha para o outro como primeiro termo. A paisagem ordena seus tamanhos e suas distâncias de acordo com nossa retina e nosso coração repara os acertos (idem, p. 19).
\end{abstract}

Este entendimento permite chegar a duas conclusões fundamentais: a primeira é que cada qual tem a missão única de revelar como a verdade lhe parece, a outra é que cada qual precisa ser fiel esta verdade. A fidelidade à verdade de cada um consagra a perspectiva do espectador e mostra que a realidade comporta diferentes perspectivas. É o que observa Margarida Amoedo em sua tese de doutoramento onde afirma que a realidade (2002): "apresenta-se em escorço o que equivale a dizer que ela se manifesta em perspectiva e a admitir que é possível ter dela diferentes perspectivas, conforme o ponto de vista a partir da qual a olhamos" (p. 282).

O ensaio Verdad y Perspectiva sugere ainda que não são pertinentes perguntas no que diz respeito à falsidade da perspectiva. O filósofo nos oferece um exemplo do que quer dizer. Ele afirma que podemos ter duas visões da Serra de Guadarrama ${ }^{6}$ conforme se a contemple a partir de $\mathrm{El}$ Escorial ou a partir de Segóia. As duas vertentes da serra oferecem visões distintas a quem as contempla não fazendo sentido se falar da verdade de uma em detrimento da outra. O texto faz clara alusão entre o que se manifesta e a posição do sujeito. Eis o texto do filósofo:

Desde o Escorial, rigoroso império de pedra e geometria, donde assento minha alma, vejo em primeiro termo o curvo braço ciclópeo que se estende de Madri a Serra de Guadarrama. O homem de Segóia, desde sua terra roxa, enxerga a vertente oposta (idem, p. 19).

\footnotetext{
${ }^{6}$ A Serra de Guadarrama é uma cadeia montanhosa que fica no centro da Península Ibérica, situada entre as serras dos Gredos (Ávila) e de Ayllón (Segóvia - Guadalajara). Ela mede aproximadamente $80 \mathrm{~km}$ e o seu pico mais alto é Peñalara com $2.430 \mathrm{~m}$ de altura. Abrange 3 comunidades autônomas espanholas:as de Castela e Leão,Castela a Mancha e Madrid,na parte central da Península Ibérica.
} 


\title{
A multiplicidade de perspectivas e a fidelidade à própria
}

Ao comentar sobre a fidelidade à própria perspectiva, Ortega y Gasset destaca a proximidade do olhar que existe entre as pessoas de uma mesma região. Embora seja sempre singular o olhar humano, no interior de um mesmo grupo cultural há mais semelhanças do que entre pessoas de grupos distintos, pois a história e as semelhanças do grupo afetam a percepção individual. Assim lembra o filósofo no ensaio De Madrid a Astúrias o los dos paisajes (1915), texto publicado em El Espectador III:

\begin{abstract}
Que o olhar asturiano, em geral, do norte é distinto do castelhano e isto não é uma maneira de dizer. Segundo parece nada ignora, a vista e o ouvido que procedem à diferenciação sofrida ao longo do movimento evolutivo (p. 256).
\end{abstract}

A diferença entre pessoas de grupos distintos que é constatável na descrição da paisagem ou dos sonhos é menos notada no uso de uma técnica. Por que motivo os sonhos das pessoas do mesmo grupo e sua sensibilidade ao ambiente são mais próximos entre eles do que dos grupos afastados? Porque é a intimidade, isto é, o que o homem tem do lado de dentro, o que melhor o diferencia. O filósofo trata deste assunto em Elogio del Murciélago (1921) publicado em El Espectador IV. Ali diz: "O homem de Calcutá e o de Paris, quando querem transportar algo usam identicamente a roda. Em contrapartida, se diferenciam quando se põem a sonhar" (p. 320). O que Ortega y Gasset quer dizer é que o uso da tecnologia é mais parecido entre pessoas de diferentes grupos culturais, pois depende menos da intimidade para seu uso.

$\mathrm{O}$ momento histórico também afeta a perspectiva com que a pessoa percebe os seres à sua volta. $\mathrm{O}$ homem ordinariamente busca o prazer e evita a dor, diz o filósofo acompanhando Sigmund Freud (1856-1939), mas algumas vezes este princípio de origem fisiológica se altera porque a circunstância social contribui para isto. A cultura afeta, portanto, o mecanismo fisiológico conferindo plasticidade à conduta. Isto faz com que "os homens que se preocupam mais em buscar prazeres que evitar as dores, outras vezes procurem o inverso" (idem, p. 31). Esta diferença na orientação comportamental tem raiz cultural porque o homem estabelece uma relação ativa com o meio e pode mudar aquilo que sua fisiologia traz. Esta plasticidade comportamental humana é que nos permite respostas diferentes das sugeridas pela biologia. As diferentes gerações vêem o mundo de modo distinto e reagem a ele de maneira diversa. 


\title{
HUMANAS
}

O homem modifica contínua e consistentemente o ambiente geográfico que lhe serve de base para a vida. Ele não só reage instintivamente ao meio, mas atua intencionalmente. Assim o diz o filósofo em Temas de viaje, também publicado em El Espectador IV: "A terra influi no homem, porém o homem não é um ser reativo, sua resposta pode transformar a terra em torno" (p. 372). A ação dirigida para mudar o meio é mais característica do modo humano de ser, pois o homem agindo intencionalmente é capaz de transformá-lo e torná-lo mais de acordo com suas necessidades. Este reconhecimento da atividade humana como indicativo do seu modo de ser revela a influência do "culturalismo" alemão. A questão se mostra no texto citado a seguir:

\begin{abstract}
A vida não é recepção do que se passa fora, antes pelo contrário, consiste em pura atuação, viver é interior, portanto, um processo de dentro para fora, em que invadimos o contorno com atos, obras, costumes, maneiras, produções segundo estilo originário que está previsto em nossa sensibilidade (idem, p. 378).
\end{abstract}

No mundo cultural, o trabalho e a produção de bens têm peso importante. Ele influi no modo como os indivíduos e as gerações perceberem o mundo, afirmou Karl Marx (1818-1883) quando estudou os movimentos da sociedade. Ortega y Gasset concorda que, pelo menos no século XIX, deu-se maior importância à economia que aos outros aspectos da vida, o que faz a teoria de Marx verdadeira, em termos gerais, como interpretação do mundo naqueles dias. Afirma em La interpretación bélica de la história (1926) um dos ensaios de El Espectador VI que: "O homem moderno vinha progressivamente convertendo-se em homem econômico. Ele se preocupava, sobretudo, em usar meios úteis. Sentia a vida como um afã utilitário" (p. 526). Portanto, o que confere credibilidade e verdade à teoria de Marx, na avaliação que dela faz Ortega y Gasset, é a circunstância histórica. Isto significa que o marxismo se foi bom como discurso do século XIX não serve para explicar o mundo no seu tempo. A teoria marxista não serviria igualmente para entender os séculos passados desde dentro, como gostava de dizer Ortega y Gasset. Se escrita na Idade Média, por exemplo, não causaria nenhum impacto. Hoje também perdeu o encanto e frescor do século XIX e no futuro representará ainda menos como forma de entender as relações humanas. Num sentido concordaria Ortega y Gasset com as análises que Georg Wilhelm Friedrich Hegel (1770-1831) fez da história da filosofia. As filosofias são históricas como propôs Hegel, embora o historicismo hegeliano tenha um erro de fundamento, que Ortega y Gasset aponta em Hegel y América (1928), publicado em El Espectador VII: 
O caso de Hegel deixa patente sonoramente o erro que há em definir o histórico como o passado. Uma concepção cautelosa do real histórico tem que contar com o futuro, com nosso futuro, não só com o nosso, enquanto futuro do pretérito. Assim esta filosofia da história não tem futuro, não tem escapatória (p. 566).

A sexualidade humana, isto é, o fato de que a humanidade é feita de homens e mulheres, é outra variável que afeta a perspectiva, observa o filósofo. A mulher, mais do que o homem, diz Ortega y Gasset em Divagación ante el retrato de la marquesa de Santillana (1918) publicado em El Espectador VIII: "não faz depender sua felicidade da benevolência do público, nem submete à aceitação ou repulsa o que é mais importante em sua vida" (p. 688). A maior independência da mulher na forma de tratar sua felicidade decorre de sua condição psicológica. As mulheres têm uma vaidade mais visível do que a do homem, mas esta vaidade afeta menos seu mundo interior. $\mathrm{O}$ homem diversamente, apesar de ostentar uma vaidade menos visível exteriormente, a cultiva mais profundamente em seu interior. Ele assim explica esta diferença de perspectiva entre homens e mulheres: "Se o talento ou a autoridade política aparecessem na face, como ocorre com a beleza, a presença da maior parte dos homens seria insuportável" (idem, p. 689).

As características psicológicas de homens e mulheres se mostram de muitos modos. Um outro exemplo de como a mulher vive mais voltada para seu íntimo está na forma de viver o recato. Para Ortega, o que a mulher pretende esconder com mais força é o que ela carrega em seu íntimo e não o seu corpo. O corpo, a mulher não importa de mostrar, mas oculta o acesso ao seu interior. Esclarece o filósofo: “os gestos de pudor não são senão a forma simbólica (...) desse recato espiritual" (idem, p. 689). As diferenças entre homens e mulheres não se restringem ao resguardo do íntimo. No mesmo texto, como já afirmou um dos autores deste trabalho: "justo por resguardar mais o seu interior é que a mulher tem mais segredos que o homem. É este recato íntimo que atrai o homem. Don Juan, por exemplo, se apaixona por uma monja e não por uma prostituta" (Carvalho, 2009, p. 338).

\section{Perspectiva e raciovitalismo}

No livro El tema de nuestro tiempo (1923), o filósofo retomou a crítica ao racionalismo e ao relativismo, estabelecida em Verdad y Perspectiva. No livro fica mais bem esclarecido que o racionalismo trabalha com a existência de verdades universais e abstratas, além de acreditar que a razão pode decifrá-las. 
Em contrapartida, o relativismo, grupo no qual o filósofo inclui os empiristas, céticos e pragmatistas, a crença é a oposta, isto é, tem-se por certo a incapacidade da razão alcançar verdades universais ou mesmo descobrir os aspectos nucleares da realidade. Estas posições marcam o debate filosófico nos tempos modernos como ele resume (1994):

\begin{abstract}
Vimos como o problema da verdade dividia os homens de gerações anteriores à nossa em tendências antagônicas: relativismo e racionalismo. Cada uma renuncia o que a outra retém. O racionalismo fica com a verdade e abandona a vida. O relativismo prefere a mobilidade da existência à quieta $\mathrm{e}$ imutável verdade (p. 163)
\end{abstract}

Ortega y Gasset entende que no século em que vivia o problema do acesso à verdade era diferente do que havia sido até então, impedindo os homens de se posicionar confortavelmente em um dos dois grupos: racionalistas ou relativistas. Foi para evitar seguir por um dos dois caminhos que ele fala de perspectiva pessoal para se chegar à verdade, admitindo, ao lado dela, a existência de uma verdade invisível. Este fato explica porque por melhor que façamos nunca chegamos à verdade completa. Os homens estão sempre desafiados a elaborar a própria perspectiva. A vida será sempre diferente a filosofia também.

A meditação orteguiana tem outro componente importante, a necessidade de superar as explicações intelectualistas do conhecimento. Este problema o filósofo examina em El origen deportivo del Estado (1924), parte integrante de El Espectador VII. Na segunda parte do ensaio lembra que o século XIX foi marcantemente utilitarista, uma interpretação da vida que emergiu das propostas intelectualistas. De início e para rejeitar o caminho proposto pelo intelectualismo lembra que "a atividade original e primeira da vida é sempre espontânea, luxuosa, de intenção supérflua, é livre expressão de uma energia preexistente" (p. 609). Assim, o esforço humano em marcar uma posição no mundo contempla o lado utilitário, mas a vida mesma experimentada na perspectiva do indivíduo é atividade desportiva, primária e criadora.

O propósito de conhecer o mundo e responder os seus desafios consagra, pois, não só o sentido da perspectiva na busca da verdade, mas a raiz vital da perspectiva. $\mathrm{O}$ filósofo afirma no mesmo ensaio: "a vida triunfou sobre o planeta graças a que em vez de ater-se à necessidade a inundou, a negou com exuberantes possibilidades" (idem, p. 611). Negou essencialmente a redução do vital a algo que o comprima como o fez o racionalismo moderno, embora isto não signifique que se possa abandonar a razão. 
Contudo, ele não precisou esclarecer este ponto, pois isto já estava bem dito em El tema de nuestro tiempo livro onde dissera que o que pretendia era "consagrar a vida que até agora era só um fato nulo e um acaso do cosmo, fazendo dela um princípio e um direito" (p. 179). Dito de outro modo como aparece no livro Introdução à filosofia da razão vital de Ortega y Gasset (2002): "o que Ortega y Gasset intenta, portanto, é usar a razão sem cair nos exageros do racionalismo, o que na prática consiste em reconhecer a vida como princípio último ao qual se reduzem às simplificações do intelecto" (p. 51). Ou podemos dizê-lo de uma maneira ainda mais radical: "não vivemos para pensar, mas pensamos para viver, (...), a razão está identificada com a vida" (CARVALHO, 2003. p. 36).

\section{Perspectiva e missão}

Levar adiante nossa vida é a missão fundamental que temos que dar conta, este é nosso compromisso mais importante. Ortega y Gasset nos coloca diante deste fato, temos apenas uma vida que nos é dada e ela não é dada pronta. Temos liberdade de fazer o que quisermos com o que nos foi dado. Ele nos diz em Pidiendo un Goethe desde dentro (1932):

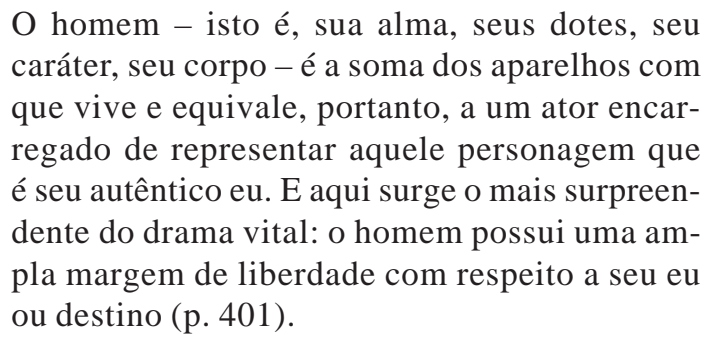

Justo por precisar ser fiel ao autêntico eu é que viver é uma tarefa difícil. Porque alguma coisa pode me acontecer ou eu posso falhar na condução desta missão é que viver é arriscado. Viver não significa repetir o que outros fizeram, mas arriscar-se a fazer o que ninguém ainda fez. Não no sentido de aplicar uma técnica ou de se valer de algum conhecimento acumulado, mas no projeto vital. E este projeto é para ser feito de uma vez, pois não há uma segunda chance. Não temos como chegar ao setenta anos e dizer: não fui fiel a mim mesmo, vou voltar aos três anos de idade e recomeçar. O que temos para realizar com nossa vida é tarefa particularíssima, e para mudar qualquer coisa temos apenas o tempo que nos resta de vida e a circunstância. 
A vida humana é, pois, na avaliação de Ortega y Gasset, uma experiência pessoal, livre, circunstancial, e intransferível, mas somente é possível a partir de dois termos primários e inseparáveis: o homem que vive e a circunstância (CARVALHO, 1996; p. 85).

Isto significa que viver tem para o filósofo um sentido moral, pois implica o compromisso de levar adiante nossa vida de um modo específico, sem se deixar vencer pela circunstância. O desafio de cada um é permanecer fiel a si mesmo, nisto consistindo a autenticidade, ser responsável com o próprio projeto vital é imprescindível para levar adiante o compromisso ético. Caso esta fidelidade não represente entrega completa ao que se é, a vida perde a autenticidade ou seu sentido e ruma para a imoralidade. "Se a vida é um conjunto de escolhas, se ela se torna aquilo do que foi composta, então as escolhas que se faz adquirem importância e a vida é constitutivamente moral" (CARVALHO, 2004. p. 67). O objetivo moral decorre fundamentalmente da possibilidade da pessoa não realizar o seu projeto vital. Ortega y Gasset usa novamente a metáfora do náufrago, mas agora com o sentido de perder-se, o homem pode se perder e não viver uma vida autêntica. No entanto, a consciência desta possibilidade representa a salvação possível na existência, explica o filósofo em Pidiendo un Goethe desde dentro: "A consciência do naufrágio, ao ser da verdade da vida, é já a salvação" (p. 397/8).

No ensaio Ideas sobre Pio Baroja (1910) publicado em El Espectador I, o filósofo esclarece melhor a missão particular que é viver autenticamente. Ali diz que quando alcançamos certa idade, por volta dos trinta anos, aprendemos a fazer um balanço de nossa existência e encontramos as primeiras manifestações de um frio moral. Por que assim ocorre? Porque não temos como mentir para nós mesmos e somos obrigados a fazer um balanço do que estamos fazendo sem fantasiar o resultado. Ele explica (1998):

Um frio que não vem de fora, mas que nasce do que há de mais íntimo e dali envia ao resto do espírito um efeito estranho (...). Não é tristeza, nem é amargura, nem é melancolia o que suscitam os trinta anos é um imperativo de verdade e uma repugnância ao fantasmagórico (p. 74).

Ao atingirmos os trinta anos não esperamos mais viver como os outros, mas queremos viver por nós mesmos, mesmo que isto seja mais difícil que repetir outrem. O imperativo de verdade nos coloca em contato com o que somos na intimidade. Ele permite descobrir aquilo que o filósofo denomina 
fundo insubornável, isto é, uma parte de nós que não admite ser ludibriada em nenhuma hipótese, nem por nós mesmos, nem pela ciência, política ou qualquer outra criação cultural. Afirma: "Queremos ser, antes de tudo, a verdade do que somos e muito especialmente queremos deixar bem claro o que sentimos do mundo" (idem, p. 75). Este é outro aspecto da perspectiva. As pessoas se tornam admiráveis se levam adiante à perspectiva única que a identifica. Não só temos uma verdade para conhecer, mas uma para viver em perspectiva.

A perspectiva singular que marca a vida de cada um traduz a ânsia de lealdade para consigo. Este fundo insubornável o filósofo compara ao eu profundo de Henry Bergson (1859-1941), pois a parte mais interior de cada um não é facilmente acessada uma vez que se encontra sob uma camada que dificulta o acesso aos elementos fundamentais deste núcleo. Eis o que explica o filósofo:

Geralmente este núcleo último e individualíssimo
da personalidade está soterrado debaixo do acú-
mulo de juízos e maneiras sentimentais que de fora
caíram sobre nós. Só alguns homens dotados de
uma particular energia conseguem vislumbrar em
certos instantes e atitudes o que Bergson chamaria
o eu profundo (idem, p. 84).

O que está claro em Ideas sobre Pio Baroja é que o eu profundo coloca cada homem diante da verdade que lhe aparece em perspectiva. A fidelidade a esta verdade revela as dificuldades do sistema moral. As regras que são impostas aos indivíduos em nossa cultura e que eles acabam seguindo, os levam para longe do seu núcleo interior. De tal forma as coisas se passam que não é raro encontrar pessoas vivendo projetos alheios, isto é, seguindo uma rota de vida que nada tem com o que ela é em seu íntimo, tornando-se assim infeliz e triste. Este é um problema do indivíduo, mas se ele se generaliza torna-se um problema social como ele esclarece: "uma cultura que não resolve este estado de permanente incongruência tem que ser radicalmente hipócrita" (idem, p. 88). A sociedade nos coloca em meio a muitas coisas que não buscamos e que não nos fazem felizes, ou que não são suficientes para fazê-lo. A falta de fidelidade a nós mesmos faz a vida parecer sem sentido, uma busca por coisas que não são fundamentais para nós.

\section{Perspectiva e ética}

No ensaio Verdad y perspectiva, Ortega y Gasset afirmou: "estamos entregues a nós mesmos, nada nos protege e nada nos dirige. Se não temos confiança em nós tudo estará perdido" (p. 20). No texto citado ele fala de um projeto vital em torno a uma verdade pessoal. 
Ao referir-se à verdade pessoal que temos que respeitar e não apenas conhecer, o filósofo sugere uma ética na perspectiva do sujeito. Em que se baseia tal proposta? Os homens possuem inclinações comuns e semelhanças na forma de ver o mundo, em especial dentro do mesmo grupo cultural. No entanto, a conduta ética nasce de um compromisso de cada pessoa com seu fundo íntimo, aspecto que reflete uma particular experiência de vida que traduz certa perspectiva.

Ao propor uma verdade pessoal como orientadora da vida, o filósofo não desconsidera os valores culturais. Este ponto merece atenção. Não se trata de obedecer cegamente aos impulsos ou à vontade, o que significa que a ética em perspectiva não se resume à satisfação dos desejos. A busca de realização dos projetos vitais é efetivada numa sociedade que reconhece o seu sentido. Este sentido é que faz o indivíduo aberto aos outros e não fechado narcisicamente no próprio egoísmo. A ética em perspectiva usa conceitos que traduzem o modo humano de ser em circunstância: vocação ou chamado íntimo; missão social, a vida como um que fazer em situação, superação de limites ou daquilo que sufoca o indivíduo e valores de nobreza pessoal. Os valores e referências objetivas conferem certa generalidade às ações, mas cada homem possui uma perspectiva própria que precisa respeitar. Perspectiva própria neste sentido de fidelidade esclarece a expressão "eu sou eu e minha circunstância, se não salvo a ela também não salvo a mim" elaborada no livro Meditaciones del Quijote. O salvar-se a si mesmo é o que o filósofo entende como "vida autêntica" ou "coincidência consigo mesmo".

Muitos aspectos contribuem para a singularidade existencial, a saber: a herança biológica, a estrutura de pensamento, a vida emocional e também a situação histórica e ambiental do indivíduo. Ortega y Gasset utiliza o conceito de vida para traduzir a existência humana entendida como realidade única cercada de elementos naturais e culturais. Como resume Marías (2004): "O homem, diz Ortega, é o problema da vida, e entende vida por algo concreto, incomparável, único: a vida é o individual" (p. 501).

Como a vida é ato contínuo o sujeito pode reconsiderar os fatos passados e reorientar suas buscas para que suas ações intencionais tenham um sentido. $\mathrm{O}$ fato de ser histórico significa que o projeto vital de cada pessoa a acompanha durante toda a vida, ou, como diz Jaime de Salas em Ortega y Gasset y la ética de la perspectiva, "a construção de uma perspectiva é tarefa interminável" (p. 95).

Em síntese, a fidelidade ao fundo insubornável não é independente da análise racional que o sujeito se obriga a fazer antes de agir e nem pode desconsiderar os valores centrais da sociedade que fazem parte da vida pessoal. Não há, portanto, contradição entre a adequação à verdade vital e o reconhecimento dos valores culturais, assunto que o pensador retomou no livro En torno a Galileo (1933). 
Ali escreveu: "A cultura é, com efeito, uma tarefa de integração e uma vontade de aceitar lealmente tudo o que, queiramos ou não, está aí constituindo nossa existência" (p. 111).

\section{Considerações finais}

Perspectiva é um problema gnoseológico examinado inicialmente em Verdad y perspectiva. Ele é fundamental no raciovitalismo orteguiano e também aparece nos estudos de ontologia e ética feitos por Ortega y Gasset. Com a noção de perspectiva o filósofo supera a redução da realidade ao embate das teses materialistas e idealistas que marcaram o século XIX.

Ao pensar a perspectiva com que cada homem olha a verdade, o filósofo chega à posição epistemológica singular: cada pessoa tem uma perspectiva da verdade à qual precisa se manter fiel. Pela comunicação a apresenta aos demais e com eles aprende a ver outras perspectivas da verdade. Pensada desta forma a questão da realidade não pode ser reduzida a um fundamento material ou espiritual para o mundo. Por outro lado, não permite invalidar as criações culturais que tem o propósito da objetividade como o são as leis da ciência.

O problema da perspectiva através da qual construímos a verdade é epistemológico, mas se abre para uma verdade pessoal que temos não só que conhecer, mas viver. O filósofo fala de um imperativo de verdade que nos coloca em contato com nossa intimidade mais funda. Temos o compromisso de ser fiel a este núcleo íntimo e isto significa que a busca de nossa verdade pessoal é a base de uma ética em perspectiva.

A fidelidade a este fundo íntimo não significa realizar todos os desejos, demanda uma análise racional da situação e considera os valores nucleares da sociedade. Neste artigo também procuramos deixar claro que para Ortega y Gasset não há contradição entre a verdade vital e os valores culturais, assunto dos ensaios de El Espectador e que será igualmente tema do livro En torno a Galileo.

Reside nisto o problema central da ética em perspectiva. Há certa tensão insuperável entre nossos desejos, vontade e as leis da cultura. O projeto vital concebido por Ortega y Gasset precisa elaborar este equilíbrio, mas a ética reflete um ideal, já que a cultura é expressão de valores e o que é objetivo na cultura surge como norma ou imperativo no sentido em que tratou Emmanuel Kant (1724-1804) o tema. A ética em perspectiva é um modelo de ética diverso do kantismo e que fica entre o que cada um é, inclusive de seus desejos, vontade e o que a sociedade propõe. Estabelecer este equilíbrio para fazer o sujeito feliz é o propósito dela. 


\section{Referências bibliográficas}

AMOEDO, M.I.A. José Ortega y Gasset: a aventura filosófica da educação. Lisboa: Imprensa Nacional - Casa da Moeda, 2002.

CARVALHO, J.M. de. Lições de Ortega y Gasset sobre a vida humana. Ética e Filosofia Política/EDUFJF, 1(1): 81-89, 1996.

CARVALHO, J.M. de. Introdução à filosofia da razão vital de Ortega y Gasset. Londrina: Cefil, 2002.

CARVALHO, J.M. de. Ortega y Gasset, um interlocutor ainda atual. In: CARVALHO, J.M. de (Org.). Atas do Colóquio José Ortega y Gasset. São João del-Rei: EDUFSJ, 2003.

CARVALHO, J.M. de. Vida e valores na filosofia da razão vital de Ortega y Gasset. In: CARVALHO, J.M. de (Org.). Problemas e teorias da ética contemporânea. Porto Alegre: EDIPUCRS, 2004.

CARVALHO, J.M. de. O conceito de circunstância em Ortega y Gasset. Revista de Ciencias Humanas, 43 (2): 331-345, 2009.

CASCALÉS, C. L'humanisme d'Ortega y Gasset. Paris: Universitaires de France, 1957.

MARÍAS, J. História da Filosofia. São Paulo: Martins Fontes, 2004.

ORTEGA Y GASSET, J. Meditaciones del Quijote. In: Obras Completas. Volume I, $2^{a}$ edição. Madrid: Alianza, 1993.

ORTEGA Y GASSET, J. Verdad y Perspectiva (El Espectador). In Obras Completas. Volume II, $3^{\text {a }}$ edição. Madrid: Alianza, 1998.

ORTEGA Y GASSET, J. Ideas sobre Pio Baroja (El Espectador). In: Obras Completas. Volume II, $3^{\text {a }}$ edição. Madrid: Alianza, 1998.

ORTEGA Y GASSET, J. El origen deportivo del Estado (El Espectador). In: Obras Completas. Volume II, $3^{\text {a }}$ edição n. Madrid: Alianza, 1998.

ORTEGA Y GASSET, J. De Madrid a Astúrias o los dos paisajes (El Espectador). In: Obras Completas. Volume II, $3^{\text {a }}$ edição. Madrid: Alianza, 1998.

ORTEGA Y GASSET, J. Elogio del Murciélago (El Espectador). In: Obras Completas. Volume II, $3^{\text {a }}$ edição. Madrid: Alianza, 1998.

ORTEGA Y GASSET, J. Temas de viaje (El Espectador). In: Obras Completas. Volume II, $3^{\text {a }}$ edição. Madrid: Alianza, 1998. 
ORTEGA Y GASSET, J. La interpretación bélica de la história (El Espectador). In: Obras Completas. Volume II, $3^{a}$ edição. Madrid: Alianza, 1998.

ORTEGA Y GASSET, J. Hegel y América (El Espectador). In: Obras Completas. Volume II, $3^{\text {a }}$ edição. Madrid: Alianza, 1998.

ORTEGA Y GASSET, J. Divagación ante el retrato de la marquesa de Santillana (El Espectador). Obras Completas. Volume II, $3^{a}$ edição. Madrid: Alianza, 1998.

ORTEGA Y GASSET, J. El tema de nuestro tiempo. In: Obras Completas. Volume III, $2^{\text {a }}$ edição. Madrid: Alianza, 1994.

ORTEGA Y GASSET, J. Pidiendo un Goethe desde dentro. In: Obras Completas. Volume IV, $2^{\text {a }}$ edição. Madrid: Alianza, 1994.

ORTEGA Y GASSET, J. En torno a Galileo. In: Obras Completas. Volume V, $2^{a}$ edição. Madrid: Alianza, 1994.

SALAS, J. de. Ortega y Gasset y la ética de la perspectiva. Estudios orteguianos (Fundación José Ortega y Gasset), 6: 89-100, 2003. 